\title{
Local Wisdom of Kasepuhan Ciptagelar: the Development of Social Solidarity in the Era of Globalization
}

\author{
Ilham Rohman Ramadhan *; Djono; Nunuk Suryani \\ Department of Teacher Training and Education, Sebelas Maret University, Indonesia \\ Email: ilham.rodhan@student.uns.ac.id
}

http://dx.doi.org/10.18415/ijmmu.v5i3.141

\begin{abstract}
Kasepuhan Ciptagelar is one of the Sundanese traditional village based on agricultural culture in West Java Province, Indonesia. Kasepuhan Ciptagelar people still hold and apply their ancestral cultural values in their daily life. The purpose of this study is to 1) know the existence of local wisdom values that exist in Kasepuhan Ciptagelar society; 2) to know the form of social solidarity values that exist in Kasepuhan Ciptagelar community and 3) Integration of local wisdom value for social solidarity development in globalization era. This research is a descriptive qualitative research, with ethnography approach. The results show that 1) Kasepuhan Ciptagelar community has some local wisdom, they are social solidarity, environment awareness, democratic, honest, responsibility and creative. The values of existing local wisdom still exist and are proven to survive in the era of globalization; 2) social solidarity in Kasepuhan Ciptagelar reflected from social interaction, trust and social awareness that exist in society; and 3) Development of social solidarity in the era of globalization can be done through the integration of local wisdom into education in School.
\end{abstract}

Keywords: Local wisdom; Kasepuhan Ciptagelar; Social solidarity; Globalization

\section{Introduction}

Indonesian society is well-known for its cultural diversity and its traditions. This noble culture and tradition comes from hundreds of tribes who inhabit the archipelago. Each of these tribes has different customs, ways of life, values, languages, and spiritual life. Local traditions are preserved in society as an identity, where the local cultural values contained within the tradition are used as guidance, are believed to be truth and sacredness by society. Cultural values then form a local wisdom that is reflected in the concept of community social solidarity in doing its activities.

In recent decades the values rooted in local wisdom are increasingly abandoned by people who consider it irrelevant to present or future life. The influx of foreign cultures is also a serious threat to the Indonesian people, especially the indigenous cultures that portray the distinctive locality of each region in the country. Mistakes in responding to globalization can result in erosion of local culture in the archipelago. The existence of local culture will sooner or later be affected by the influx of globalization in Indonesia. 
One of the way that local culture can survive is to instill its values through education. According Tilaar (2002: 9) that education is a process of sowing the seeds of culture and human civilization that live and lived by the values or visions that developed and developed in a society. Hamalik (2010: 75) also defines value as a common measure that is well-regarded by society and serves as a guide of human behavior about the best way of life. These values are a consideration to give direction, generally, to education and, especially, to curriculum development. This is what Leavis states (in Jenks., 2013: 151) that the reunification of peoples through culture can be realized through a carefully thought-out and carefully planned liberal education program. This kind of program will rise a strongly educated society that will regain the most vital features of social, political, and moral life.

To get the culture to be based on good attitude, society needs to combine idealism and realism which is essentially a combination of art and culture. Cultural characteristics of an area (which is different from other regions) is an attitude of respecting local culture so that it becomes a local advantage (Asmani., 2012: 38). Based on that, in every local wisdom that exist in the region contains virtue values in the life of nation and state. It is feared if the values of local cultural wisdom are not maintained slowly will be lost. Thus, one of the institutions that is also responsible for preserving local cultural values is through education.

One example of a community that still maintains the values of local wisdom in everyday life is the Kasepuhan Ciptagelar community. The pattern of life of Ciptagelar people still run the traditions of ancestors (karuhun) that is based on rice culture. The society of rice culture is a society that has a set of values and supernatural beliefs on rice entities. The belief persists and continues to grow until now. For the people of Ciptagelar, the belief in the rice entity is not only imprinted in the realm of values and thought, but is reflected in the ritual and daily life. The real form of their values, thought, and behavior is agriculture. Agriculture is considered as a worship activity. Agricultural activities cannot be separated from the ritual ceremony of sacred and myth.

The existence of Kasepuhan Ciptagelar society tradition during globalization era, interesting to be seen and studied from various angle of view, one of them through the educational point of view. In this case, it is related to interpreting it as a cultural heritage that can be integrated into the education in schools for the development of students' social solidarity. The purpose of this study is to 1) know the existence of local wisdom values that exist in Kasepuhan Ciptagelar society; 2) to know the form of social solidarity values that exist in Kasepuhan Ciptagelar Community and 3) Integration of local wisdom value for social solidarity development in globalization era.

\section{Methodology}

This research focuses on Kasepuhan Ciptagelar community living in Sinaresmi Village, Cisolok Subdistrict, Sukabumi District, West Java. This research uses the qualitative method with ethnography approach. Ethnographic approach is used to see the cultural heritage and local wisdom in Kasepuhan Ciptagelar community. Information on cultural heritage is derived from culturally-shaped data of directly observable materials (tools, fields, houses, sculptures, clothing), individual behavior and performances (ceremonies, games, food) and ideas and arrangements that exist in the minds of every individual.

Data collection is done through in-depth interviews, observation and documentation. Determination of informants is done by purposive sampling based on the criteria in accordance with the focus of research, so that research is focused on Kasepuhan Ciptagelar people who are directly involved in every activity in Kasepuhan. In the process of making sense of qualitative data, the data were analyzed continuously and repeatedly through three concurrent flows of activity including data reduction, data display and verification (Miles and Huberman., 1994: 312-318). 


\section{Kasepuhan Ciptagelar Community}

Ciptagelar is lembur (small village), as well as Kampung Gede, and Kasepuhan (center of cultural community) for the tari kolot (old Kasepuhan) around its culturally bound. Simply, the word Kasepuhan can refer to community groups or communities that are still alive and behaving in accordance with the old customs rules. Etymologically, Kasepuhan comes from the word "sepuh" which means Old (respected) (Kusdiwanggo., 2010: 310).

Ciptagelar's ancestor has been recorded since 1368 ago. Currently, Ciptagelar is the successor to the 19th of Kasepuhan. Kasepuhan Center inhabited since 7 Muharam 1421 Hijri or 12 April 2000. The pattern of life of Ciptagelar people still run the teachings and traditions of ancestors/ karuhun that is based on rice culture. The society of rice culture is a society that has a set of values and supernatural beliefs on rice entities. The belief persists and continues to grow until now. For the people of Ciptagelar, the belief in the rice entity is not only imprinted in the realm of values and thought, but is reflected in the ritual and daily life.

The real form of their values, thought, and behavior is agriculture. Agriculture is considered as a worship activity. Agricultural activities cannot be separated from the ritual ceremony of sacred and myth. Agriculture in Ciptagelar is currently being held in an acculturative way in two ways, namely, harbors and rice fields. In the implementation of agriculture, there are at least 32 series of rice culture rituals during a cycle of rice planting. Formerly, agriculture was only held by huma (dry land rice cultivation).

The people of Kampung Ciptagelar call themselves "Kasepuhan Pancer Pangawinan". The word 'pancer' can mean the source or origin and the 'pangawinan' derived from the word ngawin, which means "the carrier of the spear in the marriage ceremony". The word "pangawinan" according to Adimihardja (1992) is associated with the bareusan pangawinan (spear line), the special forces armed with spears Kingdom of Sunda. The meaning of the word 'Ciptagelar' itself is open or resigned. The origin of the Ciptagelar people is often associated with the descendants of King Siliwangi or one of the followers of the Sunda Pajajaran Kingdom.

The Ciptagelar community is a society which their daily life is running socio-cultural based on tatali paranti karuhun (ancestral heritage customs). Kasepuhan community is an open society, they do not close themselves from the patterns of modern cultural life if it does not conflict with tatali paranti karuhun as the basis of their culture. Understanding the meaning of life lies in the cautious attitude in speaking and good action, responsibility, and keeping promises. Patterns of cooperation, harmonious, friendly, cultured, civilized, and consistent with the values of ancestral cultural heritage are characteristic of the Kasepuhan community

\section{Local Wisdom of Kasepuhan Ciptagelar Community}

Etymologically the local wisdom consists of the word 'Wisdom': good value and 'Local': area/object. In general, local wisdom can be understood as local ideas that are wise, full of wisdom, good value, which is imprinted and followed by members of the community. Local wisdom has many functions, as revealed by Sartini (2006), that the function of local wisdom is 1) conservation and preservation of natural resources; 2) human resources development; 3) development of culture and science; 4) advice, belief, literature and taboo; 5) ethical and moral; 7) political meaning.

Atmodjo in Ayatrohaedi (1986: 37) reveals that local wisdom is the ability to absorb foreign cultures that come selectively, meaning that they are adapted to local circumstances. Such capability is very relevant to the purpose of learning History. Learners can choose and sort out which culture suits their own cultural characteristics, through the capabilities that have been developed. Ability to absorb foreign 
cultures that come selectively necessarily requires direct experience from the community around his residence. It can be done by using indigenous culture as a source of learning.

Seeing from its form, the value of local wisdom in Kasepuhan Ciptagelar consists of two forms, namely tangible (visible) and intangible (invisible). First, the form of tangible local wisdom, among them are: 1) Building/architecture. Some of the main buildings in Kasepuhan are Imah Gede (communal house), Leuit Si Jimat (rice barn), Bale Sosial (community meeting hall), Mosque, Ajeg Wayang Golek (place of puppet show) and the residence of elderly elders. 2) Traditional objects, namely mortar, clay furnace, kentongan, beduk, and the roof of rumbia. 3) Art, art tradition in Kasepuhan Ciptagelar not only used as entertainment, but also used in every custom ritual which is executed, among others is Angklung Dogdog Lojor. Angklung is played as a prayer media or thanksgiving for the produce and the balance of nature.

Second, the intangible system, which is inherited in an intangible form, passed down from generation to generation:

Environmental Care, environmental awareness of the community by the existence of forest zoning in Kasepuhan. The forest in Kasepuhan Ciptagelar is divided into 3 zones, namely Leuweung Tutupan (closed forest) which is forbidding to enter without permission, the wood in this forest should not be taken to be utilized to be anything. Then there is the Leuweung Titipan, this zone is the belt for the Leuweung Tutupan (closed forest) and Leuweung Garapan, wood in this forest zone can be utilized by the community through the permission of the community leader, and the last Leuweung Garapan, this forest can be utilized by the community freely. The people's concern is also seen from not being able to be used at all chemical fertilizers in planting rice and growing crops. Even rice cultivation can only be done once, it is easy for the land or the earth to rest for a moment, then ready to be planted again in the next year planting period.

Social Solidarity, indigenous people of Kasepuhan Ciptagelar always put social solidarity in daily life. This is reflected in every activity that they do. In Kasepuhan there is no private land, whether it is land for houses or fields and lading. All the land in the Kasepuhan area is a customary land whose use is regulated by custom. Therefore, every activity, agriculture or personal needs such as building a house or celebration, done together. In Kasepuhan society known proverb, kudu boga rasa, rumasa, ngarasa kudu hate tekad, ucaap jeung lampah, kudu akur jeung dulur, hade carek jeung saderek, kabatur tinggal makena (must get along with brother, talk good with people, against others stay apply) all Kasepuhan residents know each other, live in harmony, rarely conflict and will not object if asked for help by neighbors and relatives. The Kasepuhan never regard social status based on their possessions, but they measure it with kindness and generosity towards others.

Democratic, although the elders (sesepuh girang) have the power and the right to decide a decision, but not necessarily he can unilaterally decide something. In terms of a decision, in Kasepuhan society is always discussed first and discussed fairly. Together with the elders of Kasepuhan. The role of the elders of Kasepuhan or the so-called baris kolot is respected by the Kasepuhan people. This is reflected from the proverb kudu jadi takeucik saleuwi, kudu jadi buyar sacingkrung (must be a container purpose and bow).

Honest, the value of honesty is highly respected by Kasepuhan residents. The people of Kasepuhan strongly believe in the abstinence and restrictions that apply in tradition. The people of Kasepuhan strongly believe in kabendon or kualat (curse). In Kasepuhan Ciptagelar there is no written law here there is only oral law from generation to generation. However, in practice, all societies respect the existing law. If there are citizens who violate the law is usually directly be replied and felt by the individual concerned, such as falling ill or stricken accident. Ciptagelar area itself rarely happens criminal acts, such as theft for example. Even if there is, usually the perpetrator is a resident outside Kasepuhan area. The honesty that exists in the life of the Kasepuhan community is reflected in the proverb 'Mipit 
kudu amit, ngala kudu menta, make suci, dahar halal ulah maen kartu, maen dadu, madat, jinah, ngrinah tanpa wali (picking must be permit, take must ask, what use must be sacred or clean, eat hallal, do not gamble, marry before marriage).

Responsibility, as part of Kasepuhan customary citizens, every individual obeys all applicable customary rules. Responsibility is also visible in terms of maintaining the environment by always doing tree planting every January 1st. In addition, Kasepuhan residents are always responsible by following all the rules that apply in government, such as having a citizen ID card, following the election and so forth.

Creative, creative form of the citizen is seen from the existence of various crafts are produced, these crafts are the majority of natural-based, such as kaneron (bags made of pandanus leaves are woven and shaped in such a way), this bag usually used for daily activities such as when going to the fields. In addition, all the kitchen utensils that citizens have are the production of the community member, such as boboko (rice basket), hihid (bamboo fan), Torombol and Aseupan (bamboo rice steamer).

\section{Social Solidarity Values in Kasepuhan Society}

Solidarity is loyalty among members of social groups. The existence of high solidarity in the group depends on the trust of members of the ability of other members to do their job well. The division of tasks in groups according to the skills of each member with certain circumstances will give good results. The situation will be higher also group solidarity and sense of belonging (Huraerah and Purwanto., 2006: 7).

Furthermore, the social solidarity that Durkheim mention in Lawang (1994: 181) is a state of interpersonal and/or group relationships built on shared moral feelings and beliefs and reinforced by shared emotional experiences. Solidarity in the state of relationships between individuals and groups that underlie the common attachment in life with the support of moral values and beliefs that live in society.

Based on the results of research on Kasepuhan Ciptagelar community, social solidarity in Kasepuhan Ciptagelar reflected from social interaction, trust and social awareness that exist in society. Social interaction within Kasipuhan Ciptagelar society is still very high, this is caused by the daily social activities based on gotong royong (cooperation). In Kasepuhan Citagelar there is no private ownership, all the land in Kasepuhan is customary land. therefore, almost all agricultural activities in Kasepuhan done in mutual assistance. This is in accordance with the guidelines of life that people hold, namely kudu sarende, saigel, saabad, sapihancan (the same lightweight carrying the same weight). Geographically Kasepuhan Ciptagelar located in the hills, that effect to social interaction of the community, every home is located adjacent and located on a flat land. Indigenous activities also influence society interaction a lot. Every month there will be a traditional event that will involve the entire Kasepuhan community.

The trust that grows in the community is seen in respect of their customary heads in Kasepuhan. The people of Kasepuhan strongly believe in customary heads in their customary lead. this is seen in the form of participation and respect of the community in every customary activity. It is then about individual consciousness in this society that will shape and influence collective consciousness. Awareness in Kasepuhan Ciptagelar society is still dominated by the role of the elders of society. The role of the community elders is not pressing, but only provides the best view on a matter that the community needs. Public awareness is also influenced by the concept of self-awareness that exists in Kasepuhan society. 


\section{Integration of Local Wisdom Values in Education to Build Social Solidarity in the Era of Globalization}

According to Alexon (2010: 1) there are two important things related to the challenges and problems faced by the Indonesian education world in this globalization era. First, the challenges facing formal education institutions that have an important role in building a new Indonesian society in the era of globalization and reform. Secondly, the partially inclined education system has made Indonesians less understand and appreciate culture. Thus, modern society can be characterized by a lack of shared values and beliefs, and an increasingly severe disability in finding mutually agreed meanings. Therefore, the integration of the value of local wisdom into Education in this era of globalization becomes very important.

The essence of cultural education in the context of education in Indonesia is value education, which is about the values derived from the culture of the Indonesian nation itself to foster the personality of the younger generation (Narwanti., 2011: 17-18). The integration of the value of local wisdom can be realized through learning in schools as an effort to provide understanding to the students so as not to lose the noble values that exist, both individually, members of society, and nation and state. Each educational process should contain various forms of learning that integrate significant local content with the needs of the community, so that schools are not alienated from their local communities and cultures. Through the learning process is then learners are faced with the values of the local culture in the context of everyday life.

According Hamalik (2007: 73) education is a social process, because it serves to socialize students through the process of socialization in a society. Schools, as one educational institution, also act as a social institution, because through the institution the child is prepared to be able to plunge and active in the life of his community someday.

\subsection{Integrate the Value of Local Wisdom in Historical Learning}

In this study, the focus is the subject of history which, according to Kochhar (2008: 475) is a subject that is considered important to be able to rise a strong feeling about the intellectual attitude and integrity of the nation. Historical learning can provide an inspiration to learners that social process is the complexity of problems that occur in a society that requires understanding.

Based on the above learning history serves to make students aware of the process of change and development of society. In this case the relationship between learning history with local wisdom values Kasepuhan Ciptagelar expected to be able to develop the material and promote social solidarity through the values contained therein. Borrowing the term ethnography according to Malinowski (in Spradley., 2006: 6) is to understand the point of view of the natives. Furthermore, Spradley (2006) then explains the culture that exists in society as acquired knowledge, which people use to interpret experience and give birth to social behavior.

Based on the study of Core Competence (KI) and Basic Competency (KD) in the 2013 curriculum, the values in the local wisdom of Kasepuhan Ciptagelar community can be integrated in Core Competence (Kompetensi Inti) and Basic Competence (Kompetensi Dasar) in grade X Senior High School, about History of Indonesia, Semester 1, on the focus of Acculturation of Culture Nusantara and Hindu Buddha.

Basic Competencies (Kompetensi Dasar): 3.6 Analyze the development of community life, government, and culture during the periods of Hindu and Buddhist kingdoms in Indonesia and show examples of evidence that still apply to the life of Indonesian society today. 4.1 Present 
the reasoning results in the form of writing about the values and cultural elements that developed during the era of Hindu and Buddhist kingdom that is still sustainable in the life of the Indonesian nation today.

Selection of Acculturation material as seen in Kasepuhan Ciptagelar itself there are examples that can be observed directly by the students about the acculturation forms of Indonesian culture and HinduBuddhism that still apply to the life of Indonesian society today. Presentation of the reasoning results in KD 4.1 can be done by the teacher through the learning model based on Project Based Learning, with the result of the project in the form of students' writing. The use of project-based scientific learning is expected to improve students' social solidarity as this lesson emphasizes interaction and cooperation between students. Observing the relevance, the values of local wisdom in the Kasepuhan Ciptagelar community can be an alternative source of historical learning, especially in Sukabumi and Lebak Banten areas, that geographically adjacent to Kasepuhan Ciptagelar.

\section{Conclusion}

Indigenous people of Kasepuhan Ciptagelar is one of the people in Indonesia who lives in the values of local wisdom that they hold firmly. The local wisdom that exists in society Kasepuhan Ciptagelar that is social solidarity, care environment, democratic, honest, responsibility and creative. These values have a philosophical meaning and can consistently be a guide to life to survive in the era of globalization. Furthermore, the value of social solidarity in the Kasepuhan Ciptagelar Society is reflected in Social Interaction, Trust and Awareness. The local wisdom that has been mentioned above can be integrated into the field of Education as a foundation to build social solidarity in the era of globalization. The integration of local wisdom values is realized through learning in schools as an effort to provide understanding to the students so as not to lose the noble values that exist, whether individually, members of society, and nation and state. One of the subjects that can be used as an example for integrating local wisdom into education is historical learning.

\section{References}

Asmani, Jamal Ma'mur. (2012). Pendidikan Berbasis Keunggulan Lokal. Yogyakarta: DIVA Press.

Ayatrohaedi. (1986). Kepribadian Budaya Bangsa (Local Genius), Jakarta: Dunia Pustaka Jaya.

Alexon. (2010). Pembelajaran Terpadu Berbasis Budaya. Unit FKIP UNIB Press.

Hamalik, Oemar. (2011). Dasar-dasar Pengembangan Kurikulum. Bandung: PT Remaja Rosdakarya.

Huraerah, Abu and Purwanto. (2006). Dinamika Kelompok: Konsep dan Aplikasi. Bandung: Refika Aditama.

Jenks, Chris. (2013). Culture: Studi Kebudayaan terj. Erika Setyawati. Yogyakarta: Pustaka Pelajar.

Kochhar, S.K. (2008). Teaching of History: Pembelajaran Sejarah. Jakarta: Grasindo.

Kusdiwanggo, S. (2016). "Sakuren : Konsep Spasial sebagai Prasyarat Keselamatan Masyarakat Budaya Padi di Kasepuhan Ciptagelar," Vol. 26, No. 3, pp. 309-322.

Miles, M. B,. and Huberman, A.M. (1994). Qualitative data analysis: A Sourcebook of new methods. Thousand Oaks, CA: Sage. 
Narwanti, Sri. (2011). Pendidikan Karakter. Yogyakarta: Familia Pustaka Keluarga.

Sartini, "Menggali Kearifan Lokal Nusantara: Sebuah Kajian Filsafati”. [Online]. Available at http://filsafat.ugm.ac.id. [Accessed: Nov. 19, 2017].

Spradley, J. P. (2006). The Ethnographic Interview: Metode etnografi. Diterjemahkan oleh: Misbah Zulfa Elizabeth. Yogyakarta: Tiara Wacana.

Tilaar, H.A.R. (2002). Membenahi Pendidikan Nasional. Jakarta: R.

\section{Copyrights}

Copyright for this article is retained by the author(s), with first publication rights granted to the journal.

This is an open-access article distributed under the terms and conditions of the Creative Commons Attribution license (http://creativecommons.org/licenses/by/4.0/). 